\title{
O gótico e a brasilidade em Lúcio Cardoso
}

\author{
Fernando Monteiro de Barros \\ Universidade do Estado do Rio de Janeiro
}

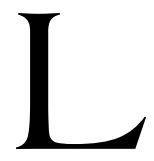

úcio Cardoso (1912-1968), escritor mineiro, transitou por vários gêneros literários, sendo, entretanto, consagrado canonicamente por sua vasta produção romanesca, que se espraia dos anos $30 \mathrm{com}$ a publicação de Maleita (1934) até o final da década de 50, com sua Crônica da casa assassinada (1959), e, postumamente, com O viajante (1973). Apontado pela crítica como escritor de romances psicológicos, também chamados romances católicos, Lúcio Cardoso efetivamente constrói uma literatura que apresenta questôes ontológicas e existenciais. Neste sentido, sua obra tem uma pretensão hermenêutica indiscutível no que busca encontrar uma resposta absoluta para o grande drama da condição humana, o grande impasse que a civilização da ciência e da técnica não logrou resolver, a grande "pedra no meio do caminho". Enquanto as massas acreditam no mito do progresso e no discurso triunfalista da sociedade industrial que lhes garante conforto e bemestar, o pensamento de Lúcio, registrado em seus vários textos, ficcionais e não ficcionais, refuta este contentamento com a ordem da superfície e empreende um mergulho no abismo, de onde pretende desentranhar a "verdade".

Hodiernamente este tipo de busca configura uma missão impossível. As narrativas contemporâneas, pós-modernas, abrem mão de encontrar ou veicular uma verdade absoluta e universal aos moldes iluministas, contentando-se com simulacros e representações. Mas Lúcio Cardoso situase ainda dentro da sensibilidade ideológica do (alto) Modernismo, a qual conta com críticos ferrenhos da sociedade do "mundo do trabalho e da razão"1 que, de diversas formas, acenam com propostas alternativas ao etos vigente, visto como insatisfatório desde o Romantismo, que já decretara a "negação

${ }^{1}$ BATAILLE, 1987, p. 37. 
radical, apaixonada e irreconciliável com o presente, ou seja, com o capitalismo e a sociedade burguesa industrial". ${ }^{2}$

Entretanto, enquanto cada artista romântico acreditava saber onde estava a "verdade", manifestação do "absoluto" assumindo as mais variadas interpretações e configurações, indo da nostalgia de um passado aristocrático e crente nas lendas e nos mitos até a consolidação democrática futura em sua vertente utópica, podemos notar entre os modernistas uma certa falta de rumo na tentativa de busca, tateante, deste "real" perdido, que avultava como sentido último de todas as questôes humanas, definitivamente não encontrado nos paradigmas oficiais da civilização moderna ocidental. ${ }^{3}$ Sob esta perspectiva, então, nos artistas da primeira metade do século XX, percebemos um anseio desesperado por coesão, seja de que ordem: o centro perdido poderá estar na utopia social, na cosmogonia mítica de eras arcaicas ou nas várias configuraçôes do irracionalismo, para dar alguns exemplos. A angústia gerada pela crise de um mundo que viveu a era da catástrofe ${ }^{4} \mathrm{em}$ um cenário epocal de esboroamento de todas as certezas ${ }^{5}$ conclama à busca, vã, de solução dos impasses, pois, ao contrário da certeza e do direcionamento românticos, o artista do Modernismo que quer propor alternativas à ordem vigente muitas vezes o faz através de um escapismo "sem destino certo, evasão amargamente errante". ${ }^{6}$ Dramaticamente, esta modernidade diagnosticada por Charles Baudelaire, aflita por descartar o modelo de "real" imposto pelo etos capitalista dominante, "se sente impotente para crer ou criar uma transcendência de conteúdo definido, dotada de sentido", o que arrasta seus poetas "a uma dinâmica de tensão sem solução e a um mistério até para si mesmos". ${ }^{7}$ Procura-se desesperadamente, assim, por alguma coerência, seja identitária, social, existencialista, política ou filosófica, que, muitas vezes, acaba por apresentar-se de forma monolítica e excludente: "o presente é tão grande, não nos afastemos. / não nos afastemos muito, vamos

\footnotetext{
${ }^{2}$ LÖWY, 1990, p. 17.

${ }^{3}$ SUBIRATS, 1987, p. 12-13.

${ }^{4}$ HOBSBAWM, 1995, p. 29-219.

${ }^{5}$ BERMAN, 1986, p. 13.

${ }^{6}$ MERQUIOR, 1996, p. 74.

${ }^{7}$ FRIEDRICH, 1991, p. 49.
} 
de mãos dadas", ${ }^{8}$ exorta o poeta que, para tal, abre mão dos suspiros, da paisagem, da mulher e dos entorpecentes.

Dialógica, no que apresenta o entrecruzamento paradoxal de várias ideologias, a obra de Lúcio Cardoso é um mundo polifônico composto por várias vozes" que, dramaticamente, sem cessar negociam o lugar da "verdade", a qual, em seu comparecimento dialético, difere da univocidade monológica do Romantismo. Em Baudelaire, pioneiro a refletir a postura ambivalente do artista perante o mundo moderno, já encontrávamos de certa maneira o estilhaçamento desta "verdade", pois em sua poética "os dois pólos, tanto o mal satânico quanto a idealidade vazia", possibilidades de evasão do "mundo banal", acabam configurando uma "fuga sem meta", que "não vai além da excitação dissonante". ${ }^{10}$

Se quisermos encontrar uma coerência traduzida em afirmação de "verdade" monolítica na obra de Lúcio Cardoso sairemos desconcertados. Se buscarmos o seu pensamento nas páginas não-ficcionais de seu Diário, então, nos depararemos com o mais flagrante paradoxo:

Apalpo e reconheço o caos que tenta me absorver. Mas ah, não devo, não posso, não tenho o direito de perder de vista a secreta ordem que, apesar de tudo, sempre me habitou. A ordem dos amotinados, é verdade, mas contudo a que me permitiu viver até agora e realizar alguma coisa. A ordem, sem a qual existir não é possível... A ordem. ${ }^{11}$

Reconhecendo a importância da ordem, Lúcio, entretanto, também não deixa de desejar a desordem: "É verdade que eu não saberia viver sem a paixão; mas é verdade também que são tão poderosas suas forças na minha alma, que o seu tumulto me mata". ${ }^{12}$ Esta antítese é resolvida dialeticamente pela arte: "sobrevivo, pela graça de ser poeta", ${ }^{13}$ pois Lúcio sabe que a paixão, canalizada para o fazer estético, é "investimento de simulação" ${ }^{14}$ Entretanto,

\footnotetext{
${ }^{8}$ ANDRADE, 1978, p. 55.

${ }^{9}$ BAKHTIN, 1997, p. 273.

${ }^{10}$ FRIEDRICH, 1991, p. 49.

${ }^{11}$ CARDOSO, 1960, p. 170.

${ }^{12}$ CARDOSO, 1960, p. 169.

${ }^{13}$ CARDOSO, 1960, p. 169.

${ }^{14}$ CARDOSO, 1960, p. 89.
} 
Lúcio também afirma, em seu "Diário de terror": "não compreendo o romance como uma pintura, mas como um estado de paixão; [...] gostaria que meus leitores se transportassem a um estado de tão alta emoção passional, que isto lhes destruísse o equilíbrio e eles se sentissem fisicamente doentes". ${ }^{15} \mathrm{~A}$ estética apolínea da aparência simulada e o turbilhão dionisíaco da essência passional, convivem e convergem, pois, na poética de um autor que não se deixa apreender facilmente em categorizações absolutizantes, estanques e reducionistas.

Alfredo Bosi afirma ser Lúcio Cardoso "um inventor de totalidades existenciais", ${ }^{16}$ mas reconhece que, em sua obra, "costuma ser penoso distinguir a prosa da poesia". ${ }^{17}$ Identificando também a confluência de preocupação estética aliada à veiculação dos temas que lhe são caros, nota Antonio Candido que este escritor constrói "universos fantasmais como quadro das tensões íntimas". ${ }^{18}$ Sabemos que, paralelamente à questão da busca de uma verdade perdida, o artista do Modernismo primará também pela busca radical de novas linguagens para a expressão artística, novas formas estéticas, mais do que nenhum outro, talvez.

Lúcio Cardoso debuta na literatura brasileira no começo dos anos trinta, decênio que, combinado com o seguinte, ficaria conhecido como "a era do romance brasileiro". ${ }^{19}$ Os anos 30 assinalam o fim da vanguarda modernista entre nós, em um momento de oficialização de uma postura estética cuja preocupação com a cultura nacional "autêntica" era vista com bons olhos pelo governo populista que se instala então com Getúlio Vargas. Entretanto, num contexto epocal de fortalecimento de regimes totalitários no Ocidente e adjacências, à beira da convulsão da Segunda Grande Guerra, as questões abordadas pela casta de artistas e intelectuais não poderiam mais se dar apenas na clave do pitoresco e do chiste. O progresso da civilização industrial não se deixava mais enganar pelos pensadores da primeira metade do século $\mathrm{XX}$, que, a suas conseqüências, atribuíam a coisificação e a

\footnotetext{
${ }^{15}$ CARDOSO, 1996, p. 744.

${ }^{16}$ BOSI, 1999, p. 414.

${ }^{17}$ BOSI, 1999, p. 415.

${ }^{18}$ CANDIDO, 1989, p. 204.

${ }^{19}$ BOSI, 1999, p.388.
} 
alienação dos indivíduos. ${ }^{20} \mathrm{O}$ pior é que muitos, como o alemão Walter Benjamin, segundo afirma Nicolau Sevcenko, haviam apostado "com convicção nas vanguardas artísticas do início do século, que por sua vez apostaram pesado na vitória da racionalidade, do maquinismo, da transformação da sociedade", na qual "a arte, a técnica e a vida se fundiriam numa unidade revitalizadora", evidenciando uma "utopia da igualdade perfeita, produzida pela razão, governada pela técnica e desfrutada pela arte". ${ }^{21}$ Mais tarde perceberam que a técnica, "derivada da razão instrumental, apropriadora, planejadora, ao invés de libertar submetera os homens ao império da máquina genocida". ${ }^{22}$ Assim, eufóricos outrora com as vanguardas e sua correspondência com "as forças do progresso", ${ }^{23}$ os artistas e pensadores do Modernismo perceberam que o mundo se convertera no oposto daquilo que se esperava a partir do concurso de tais forças propulsoras: a promessa de uma liberdade sem precedentes descambou na burocratização aprisionadora e no belicismo genocida.

Neste contexto, intelectuais e artistas operam a denegação do projeto modernizador e burguês, tanto no eixo ocidental quanto em sua periferia, atacando seus principais vetores: a "crença no progresso tecnológico como valor em si mesmo", a "concepção racionalista da cultura" e a "ruptura com o passado". ${ }^{24}$ Se muito da vanguarda do começo do século XX propunha o aniquilamento total da tradição histórica e estética do Ocidente, esta de certa forma acabará por contracenar com o novo na dialética tradição/modernidade, recorrente na literatura e na cultura brasileiras dos anos 30, como se pode conferir na primeira poesia de Carlos Drummond de Andrade e no romance de José Lins do Rego, para citarmos apenas dois nomes. Na Europa, essa dialética já se deixava entrever na obra do paraninfo do espírito moderno da contraditoriedade, Charles Baudelaire, em meados do século XIX, um exilado na modernidade, ao mesmo tempo que ambiguamente por ela fascinado. ${ }^{25}$

\footnotetext{
${ }^{20}$ ADORNO; HORKHEIMER, 1985, p. 40-41.

${ }^{21}$ SEVCENKO, 1995, p. 47.

${ }^{22}$ SEVCENKO, 1995, p. 48.

${ }^{23}$ SEVCENKO, 1995, p. 48.

${ }^{24}$ SUBIRATS, 1987, p. 16.

${ }^{25}$ SZKLO, 1995, p. 11-15.
} 
Alfredo Bosi aponta o "problema do engajamento, qualquer que fosse o valor tomado absoluto pelo intelectual participante" como sendo "a tônica dos romancistas que chegaram à idade adulta entre 30 e 40", ${ }^{26}$ como Lúcio Cardoso. Voltando-se mais para questôes relativas ao ontológico e à neurose da existência do que a voga narrativa regionalista dominante, preocupada majoritariamente com o sociológico e a neurose da sobrevivência, nem por isso Lúcio deixou de demonstrar uma preocupação com as questôes de seu tempo e com o grande tema da nacionalidade, na ordem do dia nesses tempos de retratos do Brasil.

Agrupado com Octávio de Faria e Cornélio Penna, na ficção, e ideologicamente identificado com os poetas Augusto Frederico Schmidt, Jorge de Lima e Murilo Mendes, Lúcio é comumente enquadrado, pela crítica, no rol dos intelectuais católicos dos anos 30, associados à direita e ao apego à tradição. Para o cânone, a obra de Lúcio e seus colegas ficcionistas é categorizada como romance psicológico, que, junto ao romance regionalista (José Américo de Almeida, José Lins do Rego, Graciliano Ramos, Rachel de Queiroz, Jorge Amado) e ao romance urbano de costumes (Marques Rebelo, Erico Verissimo, José Geraldo Vieira) compõe as trilhas da ficção brasileira dos anos que vão de 1930 a 1945 . Em nossa literatura, atribui-se o projeto de construção de um modelo de identidade nacional, de brasilidade, aos modernistas da década de 20 , e o comparecimento do retrato da realidade social do país ao romance regionalista de 30, marcadamente nordestino. O romance católico/psicológico é, freqüentemente, ligado mais à "sondagem psicológica e moral", ${ }^{27}$ aos conflitos de consciência e aos problemas religiosos que afligiriam o modelo de família tradicional brasileira instituído pela modernização no Brasil, devido à notoriedade de Octávio de Faria e a série de romances que constituem sua Tragédia burguesa. ${ }^{28}$ É ressaltada, nesta modalidade ficcional, a falta de apego à temática nacional e a exclusiva preocupação com valores universais: "Não fazia mais sentido, num discurso de convertido, no discurso universalizante do cristianismo, a preocupação limitada com o nacional. (...) O discurso da tradição que retoma os valores

\footnotetext{
${ }^{26}$ BOSI, 1999, p. 390.

${ }^{27}$ BOSI, 1999, p. 389.

${ }^{28}$ CÂNDIDO, 1989, p. 204.
} 
do cristianismo tornava praticamente impossível a relação cotidiana do poeta com o Brasil", ${ }^{29}$ diz Silviano Santiago, a respeito do também escritor católico Murilo Mendes, amigo de Lúcio, no artigo "A permanência do discurso da tradição no modernismo".

Entretanto, não se mostra Lúcio Cardoso totalmente despreocupado com o nacional - muito pelo contrário. Sua Minas Gerais natal lhe parece ser assaz importante, como podemos aferir de seu próprio depoimento ao suplemento literário Letras e Artes, na década de 40:

A paisagem mineira nunca me abandonou. Acho mesmo que os críticos que se detiveram sobre os meus livros, em geral, não salientaram o que de visceralmente mineiro há em mim e no que escrevo: tudo o que sei vem de Minas - e, à medida que o tempo passa, ainda é à Minas que volto, às paisagens de Minas, às cidades solitárias, antigas e magníficas de Minas. ${ }^{30}$

Sobre Lúcio, um ano após a sua morte, escreveu Hildon Rocha na revista carioca $O$ cruzeiro: "romancista, poeta, teatrólogo e pintor, Lúcio foi um dos artistas mais bem dotados de sua época... seus livros contam a história de um Brasil literário, denso, sufocado, demoníaco", ${ }^{31}$ atestando flagrantemente, com tais palavras, a existência de uma evidente construção de brasilidade na obra de Lúcio Cardoso.

A partir do resgate de parte da tradição cultural brasileira empreendido por Gilberto Freyre, em Casa-grande \& senzala (1933) principalmente, percebemos na obra de Lúcio, em particular em seu Diário e nas narrativas rurais, a afirmação de um modelo do que para ele seria a tradição brasileira enquanto marca de nossa identidade nacional "autêntica". Entretanto, encontramos neste modelo cardosiano de brasilidade fortes inflexões góticas, tanto da literatura romântica dos séculos XVIII e XIX ( $A$ luz no subsolo, Crônica da casa assassinada) quanto do cinema hollywoodiano de 30 ( $O$ desconhecido), o que nos faz concluir que sua proposta de “identidade nacional" é na verdade muito mais uma construção estética do que sociológica desta tradição, mesmo que eivada de reivindicaçóes de legitimidade e autenticidade. A

\footnotetext{
${ }^{29}$ SANTIAGO, 1989, p. 109.

${ }^{30}$ Apud FISCHER, 1946, p. 10.

${ }^{31}$ ROCHA, 1969, p. 52.
} 
partir deste prisma, a distinção entre a "verdade" e a teatralidade se inserem numa dialética que, como várias outras, povoa a "escrita do paradoxo" deste artista e intelectual tão contraditório, em uma obra verdadeiramente dialógica e polifônica.

Sua ficção compreende "histórias da província" e "histórias da cidade", entrecruzando as matrizes rurais e urbanas de nossa literatura, e dando continuidade à tensão entre tradição e modernidade presente no modernismo de 30/40 no qual se insere. Ambígua, sua produção romanesca articula elementos do vampirismo em seus mais diversos matizes, desde a versão préromântica e ultra-romântica, do gótico e do byronismo, até o registro cinematográfico dos anos 30, passando por marcas baudelairianas. Traços do Barroco, do Romantismo e do Decadentismo ditam polifonicamente o acento melancólico perceptível na obra de Lúcio. Dialógico, seu texto convive tanto com a afirmação de uma "verdade" quanto com o artifício traduzido em estetização acintosa, fazendo convergir a hermenêutica e o simulacro, Dioniso e Apolo.

Como paradigma do gótico registrável na produção ficcional de Lúcio Cardoso consideramos o primeiro romance do gênero, $O$ castelo de Otranto (1764), de Horace Walpole, no qual os principais elementos desta estética já se fazem presentes, como o castelo arruinado com suas passagens subterrâneas, os eventos sobrenaturais, a heroína solitária e o aristocrata malévolo. ${ }^{32}$ Espaço do enclausuramento e da tradição enquanto ruína alegórica, ${ }^{33}$ o castelo gótico tem seu paralelo na obra de Lúcio Cardoso com a casa-grande, decadente e fantasmática com o fim do poder oligárquico no Brasil de 30 .

$\mathrm{O}$ aristocrata malévolo da narrativa de Walpole inaugura uma linhagem de nobres malditos que engendra uma das principais figuras míticas do Romantismo, o vampiro, ${ }^{34}$ que até hoje se faz presente na produção cultural do Ocidente, tanto literária quanto cinematográfica. Paradoxal, o vampiro apresenta o dionisíaco da natureza incontrolável e o apolíneo da estetização. "A noiva de Corinto", poema em forma de balada escrito por Goethe em 1797, é apontado como sendo a primeira abordagem

\footnotetext{
${ }^{32}$ DOBRÉE, 1980, p. vi.

${ }^{33}$ BENJAMIN, 1984.

${ }^{34}$ TWITCHELL, 1997, p. ix.
} 
séria na literatura moderna do tema do vampirismo, ${ }^{35}$ e nele já se faz presente a clausura do desejo como um de seus traços constitutivos, verificável também no mais célebre texto literário do gênero, Dracula de Brahm Stoker, de 1897.36

Segundo Ernest Jones, o vampiro se caracterizaria sobretudo por dois aspectos: o fato de ser um morto e ter como hábito sugar o sangue dos vivos. ${ }^{37}$ Contudo, Jones detecta no mito associações estreitas com uma modalidade perversa de sexualidade, caracterizada pelos beijos e abraços noturnos e furtivos, ${ }^{38}$ e reconhece como conotação metafórica do vampirismo, além da dialética do senhor e do escravo configurada na "tirania político-social que suga a vida do povo", verificável nos escritos de Rousseau e Karl Marx, ${ }^{39}$ a sedução irresistível exercida pelo amante no objeto de seu desejo, sugandolhe a energia. ${ }^{40}$ Assim, o mito do vampiro reveste-se de erotismo, ${ }^{41}$ ainda que em sua manifestação monstruosa, articulando ao mesmo tempo violação de tabus e repressão sexual. ${ }^{42}$ Ao longo do século XX, os vampiros comparecem na literatura e no cinema nas mais variadas modalidades ${ }^{43}$ desde o mais sedutor, inspirado em Byron, até o mais repelente, como o Varney do folhetim de James Malcolm Rymer publicado na Londres vitoriana de 1845 a 1847 . Da mesma forma, em Lúcio Cardoso o tema também prima pela variabilidade, apesar da recorrência da clausura do desejo como um de seus aspectos mais distintivos (Aurélia, de $O$ desconhecido, e Ana, de Crônica da casa assassinada, são as personagens cardosianas que mais se destacam nesta modalidade).

Ressaltemos aqui que o uso que Lúcio Cardoso faz do mito do vampirismo é metafórico, jamais literal. Praticamente não há na ficção do

${ }^{35}$ PRAZ, 1996, p. 89.

${ }^{36}$ Este livro foi traduzido, no Brasil, por Lúcio: Drácula - o homem da noite, de Brahm Stoker. Trad. Lúcio Cardoso. Rio de Janeiro: O Cruzeiro, 1943. (Col. Mistério, 1). [Nota dos organizadores]

${ }^{37}$ JONES, 1992, p.398.

${ }^{38}$ JONES, 1992, p. 410-412.

${ }^{39}$ FRAYLING, 1992, p.34.

${ }^{40}$ FRAYLING, 1992, p. 414.

${ }^{41}$ RICHARDSON, 1992, p. 420.

${ }^{42}$ FRAYLING, 1992, p.388.

${ }^{43}$ AUERBACH, 1995, p.1-5. 
escritor mineiro a presença do sobrenatural ou a quebra da verossimilhança externa, comum no Romantismo, ${ }^{44}$ do qual o gótico e as histórias de vampiros derivam. A matriz gótica evidencia-se na obra de Lúcio pelo cenário, pela atmosfera, pelo delineamento tipológico de alguns personagens e pelo uso de alguns clichês do gênero. No gótico se incluem o supostamente irracional, o ambíguo, o não esclarecido, o caótico, o escuro, o escondido, o secreto, ${ }^{45}$ chaves tanto para as teorias psicanalíticas de Freud ${ }^{46}$ como para as inquiriçôes ontológicas do chamado "romance psicológico" brasileiro, no qual Lúcio Cardoso é enquadrado pela história da literatura brasileira. Para Anne Williams, autora de Art of darkness: a poetics of Gothic (1995), haveria duas modalidades de enredo no gótico literário: o feminino, criado por escritoras como Ann Radcliffe e as irmãs Brönte, e o masculino, produzido por escritores como Horace Walpole, Matthew Lewis e Brahm Stoker. O Gótico feminino, cômico, traz invariavelmente em seus enredos uma heroína desprotegida mas racional e sensata, hospedada ou empregada em um castelo soturno e misterioso presidido por um senhor aparentemente vilanesco que ela descobre ser bondoso no fim e com quem acaba se casando. Os eventos aparentemente sobrenaturais acabam por se explicar à luz da razão. ${ }^{47} \mathrm{No}$ gótico masculino, trágico, temos a ruína do pariarcalismo decretada por potências "femininas" (irracionais, dionisíacas), encarnadoras da alteridade para a razão ocidental, como a morte e a sexualidade, ${ }^{48}$ num embate entre natureza e cultura, atingindo seu clímax com a transgressão e a violação dos tabus. ${ }^{49}$

A "lição neogótica" ${ }^{50}$ que podemos entrever na obra cardosiana nos parece ser a da tradição masculina, da qual o tema do vampirismo constitui um de seus desdobramentos. Marcas de uma goticidade fantasmagórica e vampírica podem ser entrevistas na novela $O$ desconhecido (1940), em que o protagonista, andarilho errante, chega a uma fazenda arruinada conforme

\footnotetext{
${ }^{44}$ ABRAMS, 1979, p.11-12.

${ }^{45}$ WILLIAMS, 1995, p. 8.

${ }^{46}$ WILLIAMS, 1995, p.239-248.

${ }^{47}$ WILLIAMS, 1995, p. 135-140.

${ }^{48}$ WILLIAMS, 1995, p. 108-114.

${ }^{49}$ WILLIAMS, 1995, p. 172.

${ }^{50}$ PICCHIO, 1997, p. 540.
} 
as do vale do Paraíba fluminense, que viveram seu apogeu aristocrático e escravocrata antes da consolidação da hegemonia burguesa entre nós, e conhece Aurélia, a dona da fazenda, quando esta chegava em sua caleça.

$\mathrm{Na}$ esteira do aspecto poseur da obra de Lúcio Cardoso, $O$ desconhecido inscreve o cenário arruinado das fazendas cafeeiras do Brasil no Gótico hollywoodiano. A cena inicial de José Roberto perguntando pela fazenda dos Cata-Ventos na pequena cidade, a reação dos moradores, sua ida a pé pela estrada e o encontro com o antigo coche nos faz lembrar as cenas iniciais dos filmes Nosferatu (1922), de Murnau, ${ }^{51}$ e Dracula (1931), de Todd Browning, com Bela Lugosi no papel-título. ${ }^{52} \mathrm{O}$ romance de Brahm Stoker não apresenta, como os filmes, a longa caminhada de Jonathan Harker pela estrada até a chegada do coche que o conduziria ao castelo do vampiro. ${ }^{53}$ A plasticidade das cenas cardosianas dialoga intertextualmente e interdiscursivamente com o legado cinematográfico. José Roberto "deixara a estação, seguira a esmo, sem que ninguém soubesse lhe indicar ao certo onde ficava situada a fazenda dos CataVentos. Todos a quem fazia a pergunta abanavam a cabeça, fixavam o vago, como se procurassem ligar aquele nome a uma imagem perdida". ${ }^{54}$ Nos filmes de Murnau e Browning, do mesmo modo, os habitantes dos vilarejos negam-se a dar a Jonathan Harker a informação sobre o local do castelo do conde Drácula. Assim também como nos filmes, José Roberto caminha a pé na estrada que vai dar na fazenda dos Cata-Ventos: "Anoitecia. A sombra roxa do crepúsculo invadia toda a paisagem. [...] ...era como se aquela estrada conduzisse a um território proibido... [...] O homem continuava a caminhar, o coração opresso. Uma cruz plantada à beira da estrada obrigou-o a se deter um minuto, os olhos baixos. [...] Nesse momento, erguendo a cabeça, avistou no fundo da estrada uma nuvem de poeira, uma enorme nuvem que parecia aumentar e se aproximar". ${ }^{55}$ José Roberto avista o coche de Aurélia se aproximando do mesmo modo como, nos filmes, Jonathan Harker avista o coche de Drácula: "Fixou a vista, julgou distinguir um carro. [...] ...tudo ali adquiria um aspecto sobrenatural,

${ }^{51}$ SKAL, 1990, p. 51.

52 SKAL, 1990, p. 134-135.

${ }^{53}$ STOKER, 1993, p.18-19.

${ }^{54}$ CARDOSO, 1969, p. 115.

${ }^{55}$ CARDOSO, 1969, p. 115. 
e aquele carro, rolando dentro da sombra roxa do crepúsculo, não fugia ao sortilégio que embebia as coisas". ${ }^{56} \mathrm{O}$ carro de Aurélia, assim como sua fazenda, inscreve-se na ordem da ruína alegórica, metaforizando um passado extinto, além de apresentar elementos que o inscrevem na parafernália do Gótico:

...era um desses coches antigos, remanescentes do poderio de tantas famílias que o orgulho encerra no esplendor efêmero da província... [...] Nada fora alterado naquele estranho veículo: eram as mesmas bambinelas de veludo usado, as pesadas cortinas de damasco, os arabescos de ouro sujo. Todo ele, mesmo o cocheiro vestido de negro e a magra parelha de cavalos, guardava um aspecto exótico, irreal. [...]...julgou distinguir uma face maldosa que o fitava de dentro do coche. ${ }^{57}$

A casa-grande da fazenda de Aurélia condiz com o cenário dos romances góticos e filmes de terror, tal qual castelo de Drácula, conforme atesta Mario Carelli: "a fazenda dos Cata-Ventos não deixa de evocar a residência senhorial de $O$ barão, de Branquinho da Fonseca ou o palácio [sic] de Nosferatu do cineasta Murnau" ${ }^{58}$ Alegoria de um passado morto, a casa-grande da fazenda de Aurélia não apresentava "nenhum adorno, nenhum detalhe mais agradável à vista, nada, senão vagas reminiscências de uma outra época, testemunho do fausto de antigos senhores cuja existência tinha enchido de rumor o lento escoar de muitos lustros", ${ }^{59}$ atestando mais uma vez o dado de intertextualidade com os castelos góticos, e intratextualidade com as outras casas-grandes presentes na obra de Lúcio Cardoso (A luz no subsolo, Crônica da casa assassinada). Tal como nas narrativas góticas literárias, temos também aqui a presença da galeria de retratos dos antepassados: ${ }^{60}$ "No rápido olhar que relanceou para dentro, percebeu a moldura de dois ou três retratos pendurados à parede, $\mathrm{o}$ brilho de um candelabro e algumas mangas de vidro esparsas na obscuridade" ${ }^{61}$ E o clichê gótico dos "olhos que espiam" se faz presente:

\footnotetext{
${ }^{56}$ CARDOSO, 1969, p. 115.

${ }^{57}$ CARDOSO, 1969, p. 115.

${ }^{58}$ CARELLI, 1988, p.120.

${ }^{59}$ CARDOSO, 1969, p. 119-120.

${ }^{60}$ WILLIAMS, 1995, p. 45.

${ }^{61}$ CARDOSO, 1969, p.121.
} 
José Roberto teve a intuição de que alguém o espreitava. Levantouse com um movimento rápido e voltou a cabeça, sondando as moitas escuras. Nada distinguiu, porém. Em torno dele as coisas estavam submersas no mais absoluto silêncio. Abaixou-se de novo, sentindo, apesar disso, que a impressão de dois olhos vigilantes não o abandonava. ${ }^{62}$

Como não poderia deixar de ser, aqui também o espaço apresenta elementos comuns à poética do Gótico, pois, além do dado da casa-grande arruinada temos também nesta narrativa o comparecimento de uma natureza noturna e sombria, freqüentemente com os elementos em fúria, como a cena da tempestade que abre a trama e o uivar agourento dos cães ferozes que José Roberto freqüentemente ouve na fazenda.

Há uma extraordinária semelhança entre o início do enredo de $O$ desconhecido e o de Dracula, de Brahm Stoker, considerado por muitos como sendo a culminância do romance gótico: "Drácula é a obra maior da literatura gótica inglesa. Sua inserção dialogal com um conjunto de obras do Romantismo não pede maiores justificativas". ${ }^{63}$ Anne Williams ressalta que o romance de Stoker inverte o enredo gótico tradicional no que Jonathan Harker, aprisionado no castelo do conde Drácula, é ironicamente colocado no papel feminino da heroína dos romances góticos masculinos, a "donzela perseguida". ${ }^{64}$ Para Williams, a figura de Drácula, muito mais do que a suposta encarnação de um Pai Terrível, seria a encarnação da Mãe Terrível, já que seus domínios se inscrevem na linha do dionisíaco feminino: escuridão, loucura, sangue. ${ }^{65}$ No auge do capitalismo burguês da era vitoriana, Drácula representa o absolutamente outro: ele é oriental (do leste europeu), não ocidental; é aristocrata, não burguês; paradoxalmente morto-vivo. ${ }^{66}$ Drácula é uma criatura ligada a um passado arcaico e supersticioso, anacrônico em uma era de positivismo e cientificização da sociedade. Sua maior ameaça é a de desencadear um tipo de sexualidade incontrolável no seio do conservadorismo

\footnotetext{
${ }^{62}$ CARDOSO, 1969, p.198.

${ }^{63}$ MENEZES, 1991, p. 58.

${ }^{64}$ WILLIAMS, 1995, p. 124.

${ }^{65}$ WILLIAMS, 1995, p. 122-123.

${ }^{66}$ WILLIAMS, 1995, p. 122-123.
} 
burguês da classe-média vitoriana. Vampiros são sobreviventes de um passado extinto, representando tudo que o conhecimento racional e científico rejeita. ${ }^{67}$

Para Walter Benjamin, a tradição compreende a natureza e a história, e, com o predomínio da razão ocidental, foi pela modernidade soterrada. Entretanto, reconhecendo o que na tradição há de indomável e irredutível ao controle racionalista, admite que ela ocasionalmente irrompe das profundezas onde havia sido enterrada. Para nós, o vampiro é o paradigma por excelência deste conceito de tradição, pois evoca o que há de exorcizado na natureza (as pulsões de Eros e de Tânatos) e na história (o feudalismo e a aristocracia). "O Antigo Regime é o pecado oculto do Estado moderno", diz Karl Marx. ${ }^{68}$ A luta dos defensores da modernidade é a luta contra o passado, e "as reminiscências deste passado sempre vêm importuná-los". ${ }^{69}$ Para Benjamin, "a modernidade carrega a Antigüidade como um mau espírito (wie einen Alb) que teria vindo importuná-la em seu sono", ${ }^{70} A l b$, ou $A l p$, querendo dizer "mau demônio, fantasma que à noite vem se postar no peito de quem dorme e provoca pesadelos" ${ }^{71}$

A tradição como a casa-grande arruinada presidida pelo feminino perverso e enclausurado, tal como se coloca em $O$ desconhecido, não deixa de articular estas questões em relação a um momento onde a busca pelo paradigma de brasilidade estava na ordem do dia. A narrativa cardosiana, assim, além das questôes ontológicas e universais que aborda, toca também o dedo em uma ferida que não quer cicatrizar, posto todas as tentativas de "invenção do Brasil moderno": ${ }^{72}$ a sobrevivência alegórica e fantasmática do Brasil senhorial e oligárquico nestes anos de implementação de um novo modelo de Brasil. $O$ desconhecido, de 1940, inscreve-se em cheio dentro do longo período da ditadura Vargas (1930-1945) que perseguiu tal empreendimento "modernizador".

\footnotetext{
${ }^{67}$ BELSEY, 1994, p.176.

${ }^{68}$ Apud MATOS, 1995, p.39.

${ }^{69}$ Apud MATOS, 1995, p. 39.

${ }^{70}$ Apud MATOS, 1995, p. 39.

${ }^{71}$ Apud MATOS, 1995, p. 73.

${ }^{72}$ HERSCHMAN; PEREIRA, 1994, p. 12.
} 
Isso atestaria a existência de um dado "sociológico" na obra de Lúcio Cardoso, não nos esquecendo, porém, que a eleição de um paradigma de tradição de brasilidade por parte de Lúcio é, antes de tudo, uma construção estética desta tradição, decalcada intertextualmente do gótico literário e cinematográfico, e, assim, contribuindo ainda mais para a evidência do dialogismo no texto cardosiano.

O pensamento de Lúcio Cardoso acerca do Brasil, portanto, retiraria da tradição apontada por Silviano Santiago em seu anteriormente citado artigo, o arcaico e a crueldade. Anti-moderno, Lúcio opõe o paradoxo à doxa, a transgressão à norma e a morte e o luto à saúde e à vitalidade.

Para Alfredo Bosi, Lúcio Cardoso insere-se em uma família de escritores que aprofundam "a sondagem dos veios subjetivos", em um "clima neo-romântico saturado de valorações morais e imagens religiosas derivadas da tradição" . ${ }^{73}$ Os "traços de exaltação romântica", ${ }^{74}$ para Bosi, são a marca de sua poética. Já Tristão de Athayde relativiza esta visão sobre Lúcio, ao considerar em sua obra o entrecruzamento tanto da hermenêutica romântica como da estetização: "O que há nele é um dionisíaco de aparência apolínea", ${ }^{75}$ corroborado por Manuel Bandeira: “o romancista é grande precisamente pelo poeta que o informa" ${ }^{76}$

Contraditória, a obra de Lúcio Cardoso, assim, tanto propõe um resgate das essências, "verdadeiras", como também, ao mesmo tempo, recorre sem peias a várias modalidades de esteticismo, num processo contínuo de teatralização e fingimento poético. Concluímos então com a afirmativa de que o texto como verdade e o texto como mentira convivem e convergem na obra do autor mineiro, em constante tensão dialética, tal como os textos ao mesmo tempo ontológicos e plásticos da literatura gótica, esboroando-se em ruínas e ardências enquanto, nas galerias sombrias dos castelos, portando belos castiçais e arrastando pelo chão suas longas capas negras, marcham e dançam, em procissão solene e melancólica, os fantasmas e os vampiros.

\footnotetext{
${ }^{73}$ BOSI, 1996.

${ }^{74}$ BOSI, 1996.

${ }^{75}$ ATHAYDE, 1996, p. 773.

${ }^{76}$ BANDEIRA, 1996, p. 768.
} 


\section{Referências Bibliográficas}

ABRAMS, M. H. The Romantic period. In: The Norton anthology of English literature. 4. ed. New York: W.W. Norton \& Company, 1979. V. 2.

ADORNO, Theodor W.; HORKHEIMER, Max. Dialética do esclarecimento: fragmentos filosóficos. Trad. Guido Antonio de Almeida. Rio de Janeiro: Jorge Zahar, 1985.

ANDRADE, Carlos Drummond de. Mãos dadas. In: . Reunião. 9. ed. Rio de Janeiro: José Olympio, 1978. p. 55.

ATHAYDE, Tristão de. Meio século de presença literária. In: CARDOSO, Lúcio. Crônica da casa assassinada. Edição crítica coord. por Mario Carelli. 2. ed. Espanha: ALLCA XX; São Paulo: Scipione Cultural, 1996. (Colección Archivos, 18).

AUERBACH, Nina. Ourvampires, ourselves. Chicago: The University of Chicago Press, 1995.

BAKHTIN, Mikhail. Problemas da poética de Dostoiévski. Trad. Paulo Bezerra. 2. ed. Rio de Janeiro: Forense Universitária, 1997.

BANDEIRA, Manuel. Lúcio Cardoso. In : CARDOSO, Lúcio. Crônica da casa assassinada. Edição crítica coord. por Mario Carelli. 2. ed. Espanha: ALLCA XX; São Paulo: Scipione Cultural, 1996. (Colección Archivos, 18).

BATAILLE, Georges. O erotismo. Trad. Antonio Carlos Viana. Porto Alegre: L\&PM, 1987.

BELSEY, Catherine. Desire: love stories in Western culture. Oxford: Blackwell, 1994.

BENJAMIN, Walter. Origem do drama barroco alemão. Tradução, apresentação e notas: Sérgio Paulo Rouanet. São Paulo: Brasiliense, 1984.

BERMAN, Marshall. Tudo que é sólido desmancha no ar: a aventura da modernidade. Trad. Carlos Felipe Moisés, Ana Maria L. Ioriatti. São Paulo: Companhia das Letras, 1986.

BOSI, Alfredo. História concisa da literatura brasileira. 36. ed. São Paulo: Cultrix, 1999. . Um grande folhetim tumultuadamente filosófico. In: CARDOSO, Lúcio. Crônica da casa assassinada. Edição crítica coord. por Mario Carelli. 2. ed. Espanha: ALLCA XX; São Paulo: Scipione Cultural, 1996. (Colección Archivos, 18). 
CÂNDIDO, Antonio. A educação pela noite \& outros ensaios. 2. ed. São Paulo: Ática, 1989.

CARDOSO, Lúcio. Diário I. Rio de Janeiro: Elos, s/d. [1960].

. Diário de terror. In: . Crônica da casa assassinada. Edição crítica coord. por Mario Carelli. 2. ed. Espanha: ALLCA XX; São Paulo: Scipione Cultural, 1996. (Colección Archivos, 18).

. Três histórias de provincia: Mão vazias, $O$ desconhecido e A professora Hilda. 2. ed. Rio de Janeiro: Bloch, 1969.

CARELLI, Mario. Corcel de fogo: vida e obra de Lúcio Cardoso (1912-1968). Trad. Júlio Castañon Guimarães. Rio de Janeiro: Guanabara, 1988.

DOBRÉE, Bonamy. Introduction. In: RADCLIFFE, Ann. The mysteries of Udolpho. Oxford: Oxford University Press, 1980.

FISCHER, Almeida. Depoimento de Lúcio Cardoso. Letras e Artes. Rio de Janeiro, 10 nov. 1946, p. 10.

FRAYLING, Christopher. Vampyres: Lord Byron to Count Dracula. London: Faber and Faber, 1992.

FRIEDRICH, Hugo. Estrutura da lírica moderna. Trad. Marise M. Curioni. 2. ed. São Paulo: Duas Cidades, 1991.

HERSCHMANN, Micael M.; PEREIRA, Carlos Alberto Messeder. O imaginário moderno no Brasil. In: . (Org.). A invenção do Brasil moderno: medicina, educação e engenharia nos anos 20-30. Rio de Janeiro: Rocco, 1994.

HOBSBAWM, Eric. Era dos extremos: o breve século XX: 1914-1991. Trad. Marcos Santarrita. São Paulo: Companhia das Letras, 1995.

JONES, Ernest. On the vampire. In: FRAYLING, Christopher. Vampyres: Lord Byron to Count Dracula. London: Faber and Faber, 1992.

LÖWY, Michael. Romantismo e messianismo: ensaios sobre Lukács e Walter Benjamin. Trad. Myrian Veras Baptista, Magdalena Pizante Baptista. São Paulo: Perspectiva/Edusp, 1990.

MATOS, Olgária C. F. Os arcanos do inteiramente outro: a Escola de Frankfurt, a melancolia e a revolução. 2. ed. São Paulo: Brasiliense, 1995.

MENEZES, Aluísio Pereira de. De sexo. Jeito de todos os vampiros: arte e transmissão. Rio de Janeiro, 1991. Tese (Doutorado em Teoria Literária) Faculdade de Letras, Universidade Federal do Rio de Janeiro. 
MERQUIOR, José Guilherme. De Anchieta a Euclides: breve história da literatura brasileira I. 3. ed. Rio de Janeiro: Topbooks, 1996.

PICCHIO, Luciana Stegagno. História da literatura brasileira. Trad. Pérola de Carvalho, Alice Kyoko, rev. e atual. bibliográfica de Paulo Roberto Dias Pereira. Rio de Janeiro: Nova Aguilar, 1997.

PRAZ, Mario. A carne, a morte e o diabo na literatura romântica. Trad. Philadelpho Menezes. Campinas: Editora da UNICAMP, 1996.

RICHARDSON, Maurice. The psychoanalysis of Count Dracula. In: FRAYLING, Christopher. Vampyres: Lord Byron to Count Dracula. London: Faber and Faber, 1992.

ROCHA, Hildon. Um ano sem Lúcio. O cruzeiro, Rio de Janeiro, 11 set. 1969, p. 52.

SANTIAGO, Silviano. Nas malhas da letra. São Paulo: Companhia das Letras, 1989.

SEVCENKO, Nicolau. O enigma pós-moderno. In: OLIVEIRA, Roberto Cardoso de et alii. Pós-modernidade. 5. ed. Campinas: Editora da UNICAMP, 1995.

SKAL, David J. Hollywood Gothic: the tangled web of Dracula from novel to stage to screen. New York: W.W. Norton \& Company, 1990.

STOKER, Brahm. Dracula. London: Penguin Books, 1993.

SUBIRATS, Eduardo. Da vanguarda ao pós-moderno. Trad. Luiz Carlos Daher, Adélia Bezerra de Menezes, Beatriz Canabrava. 3. ed. ampl. São Paulo: Nobel, 1987.

SZKLO, Gilda Salem. As flores do mal nos jardins de Itabira; Baudelaire e Drummond. Rio de Janeiro: Agir, 1995.

TWITCHELL, James B. The living dead: a study of the vampire in Romantic literature. Durham, N.C.: Duke University Press, 1997.

WILLIAMS, Anne. Art of darkness: a poetics of Gothic. Chicago: The University of Chicago Press, 1995. 


\section{Resumo}

Este trabalho desenvolve o percurso intertextual do Gótico literário anglosaxão do século XVIII na escrita do romancista mineiro Lúcio Cardoso (19121968), em seus vários desdobramentos, como a tese do feminino enquanto agente destruidor do patriarcalismo, as marcas do Gótico hollywoodiano, e os traços do vampirismo literário, em suas diversas manifestaçôes. $\mathrm{O}$ desejo enquanto clausura e o pastiche intratextual convivem na narrativa cardosiana aqui estudada, que exibe o comparecimento, dialético, tanto da "verdade" da hermenêutica quanto da "mentira" da teatralização.

\section{Abstract}

This work traces the intertextual presence of eighteenth-century Anglo-Saxon Gothic literature in the writing of Brazilian novelist Lúcio Cardoso (19121968), in its many unfoldings, such as the thesis of the female as the destroyer of patriarchalism, the trappings of Hollywood Gothic, and the marks of literary vampirism in its several manifestations. The concept of desire as imprisonment and the intratextual pastiche go hand in hand in the "cardosian" narrative here studied, which exhibits the dialectic presence of both the "truth" of Hermeneutics and the "deception" of theatricality. 